Original Research Paper

\title{
Optimization of Hydrolysis Conditions for the Production of Iron-Binding Peptides from Scad (Decapterus maruadsi) Processing Byproducts
}

\author{
${ }^{1}$ Wenting Zhang, ${ }^{1}$ Yanan Li, ${ }^{1}$ Jie Zhang and ${ }^{1,2,3}$ Guangrong Huang \\ ${ }^{1}$ College of Life Sciences, China Jiliang University, Hangzhou, China \\ ${ }^{2}$ Key Lab of Marine Food Quality and Hazard Controlling Technology of Zhejiang Province, Hangzhou, China \\ ${ }^{3}$ National and Local United Engineering Lab of Quality Controlling Technology and Instrument for Marine Food, \\ Hangzhou, China
}

Article history

Received: 22-08-2016

Revised: 25-09-2016

Accepted: 15-10-2016

Corresponding Author:

Guangrong Huang

College of Life Sciences, China

Jiliang University, Hangzhou,

China

Email: grhuang@126.com

\begin{abstract}
The scad (Decapterus maruadsi) processing byproduct (SPB) was hydrolyzed by four commercial enzymes, namely, trypsin, flavourzyme, protamex and alcalase, for preparing high Iron-Binding Capacity (IBC) hydrolysate. Alcalase was the best choice for obtaining high IBC hydrolysate from SPB. Response surface methodology using a central-composite design was employed to optimize the enzymatic hydrolysis conditions with alcalase to obtain a maximum hydrolysate yield from the SPB with high iron-binding capacity. The best alcalase hydrolysis conditions were as following: Hydrolysis temperature of $46^{\circ} \mathrm{C}$, enzyme substrate ratio of $6040 \mathrm{U} / \mathrm{g}$-protein and hydrolysis time of $66 \mathrm{~min}$, respectively. Under these optimal hydrolysis conditions, the predicted ironbinding capacity was $317.2 \mu \mathrm{g} \mathrm{g}^{-1}$, which was consistent with the average of three replicates of $296.2 \mu \mathrm{g} \mathrm{g}^{-1}$ obtained in the validation experiments. The IBC of hydrolysate did not displayed linear relationship with antioxidative ability or the Degree of Hydrolysis (DH). Results indicated that the alcalase hydrolysate from scad processing byproduct can be developed into iron supplant ingredients in functional foods.
\end{abstract}

Keywords: Decapterus Maruadsi, Scad, Byproducts, Enzymatic Hydrolysis, Response Surface Methodology, Iron-Binding Capacity, Antioxidative

\section{Introduction}

The scad (Decapterus maruadsi), belongs to the family of mackerel, plays an important role in Chinese marine fishing industry economics and its production in China reached 540,000 tons in 2009 (Zhong et al., 2012). In Southern China, the peak of scad harvest is during the summer. Because of dark skin, summer high temperature, easy to oxidation and off-putting flavor (Thiansilakul et al., 2007), this fish is limited to process high-valued products. Therefore, the scad is usually processed into fish feedstuffs or fertilizer or used for producing fish oil. When it was used for fish oil, a lot of byproducts, mainly composited of head, skin, bone and others, would be included. These Scad Processing Byproducts (SPB) contained more than 50\% protein (dry basis). Utilization of these marine lowvalue fish or fish processing byproducts to produce biological active peptides has become a research hotspot, such as antioxidative activity (Jiang et al., 2014), antihypertensive activity (Forghani et al., 2016), antimicrobial activity (Battison et al., 2008), antifreeze activity (Wang et al., 2014b), anticoagulant activity (Jung and Kim, 2009), metal elements chelating activity (Jung and Kim, 2007), anti-cancer activity (Picot et al., 2006), HIV-1 protease inhibitory activity (Lee and Maruyama, 1998) and appetite suppressant activity (Cudennec et al., 2008). The SPB contained high content of protein and suitable for producing highvalue biological activity products. Two antioxidative peptides (His-Asp-His-Pro-Val-Cys and His-Glu-LysVal-Cys) had been isolated and purified from round scad muscle protein commercial proteases hydrolysates (Jiang et al., 2014). Thiansilakul et al. (2007) also studied the composition of defatted round scad protein hydrolysate with antioxidative activity. Two endogenous proteases, cathepsin L and MBSP, were isolated from blue scad skeletal muscle (Zhong et al., 
2012). However, no information regarding the ironbinding peptides from scad processing byproduct hydrolysate has been reported.

Iron is one of the most essential trace elements for human. Iron deficiency will cause many diseases. Iron is absorbed in the human intestine and many factors influence iron absorption. Generally, iron in plant foods is less absorbed than that in animal foods. Many animal proteins enhance iron absorption because they are digested into small peptides with the special amino acids or free amino acids, such as aspartic acid, histidine, glutamic acid and cysteine (Swain et al., 2002). These amino acids in free or small peptides can bind iron to form soluble complexes, which were stable under human acid stomach conditions or alkaline intestinal conditions and enhance iron absorption. The iron-peptide complex entered into enterocyte brush border membrane as soluble iron form and therefore, the iron was transported with blood through ferroportin 1, which enhanced iron absorption (Fuqua et al., 2012; Wang et al., 2014a). In recent years, many researchers had good interested in small peptides with high iron-binding ability prepared from food sources.

Various edible protein hydrolysates had high IronBinding Capacity (IBC) or iron bioavailability, such as spirulina protein (Kim et al., 2014), mackerel processing byproducts (Zhang et al., 2015), shrimp processing byproducts (Huang et al., 2012), anchovy muscle (Wu et al., 2012), lactoglobumin (Wang et al., 2014a), soybean (Zhang et al., 2014), fish collagen (Huang et al., 2015) and chickpea protein (Torres-Fuentes et al., 2012). However, there was no literature about enzymatic hydrolysate with ironbinding capacity from scad processing byproduct.

In this study, the preparation of hydrolysate with high iron-binding capacity from scad processing byproduct was investigated. Response Surface Methodology (RSM) using a central composite design was employed to optimize the enzymatic hydrolysis conditions with alcalase to obtain a maximum ironbinding capacity from the SPB, including temperature, $\mathrm{pH}$, time and enzyme addition quantity.

\section{Materials and Methods}

\section{Material}

The SPB were obtained from Zhoushan city, P.R. China. Samples were washed by tap water, drained and then chopped into slurry. The slurry was mixed with isopropyl alcohol and heated reflux at $80^{\circ} \mathrm{C}$ for $6 \mathrm{~h}$ in order to wipe off fat. After reflux, it was dried at $65^{\circ} \mathrm{C}$ to violate the isopropyl alcohol. The defatted SPB was smashed and stored at $-20^{\circ} \mathrm{C}$. The commercial proteases including alcalase (200 U/mg), flavourzyme (1200
$\mathrm{U} / \mathrm{mg}$ ), protamex $(2100 \mathrm{U} / \mathrm{mg})$ and trypsin $(50 \mathrm{U} / \mathrm{mg})$ were obtained from local chemical company. All other chemicals were of analytical grade.

\section{Preparation of Enzymatic Hydrolysates}

Defatted SPB powder was mixed with $0.05 \mathrm{M}$ Tris buffer and solid content was fixed at $5 \%(\mathrm{w} / \mathrm{v})$ based on protein content. The buffer $\mathrm{pH}$ was adjusted according to the selected commercial proteases and the solution was heated and waved at $150 \mathrm{r} / \mathrm{min}$ and proteases' recommendatory temperatures (Table 1) for $10 \mathrm{~min}$. Then various commercial proteases were added into the solution at $7500 \mathrm{U} / \mathrm{g}$ based on protein content. The hydrolysis reaction was sustained for $4 \mathrm{~h}$ and then the mixture was boiled for $15 \mathrm{~min}$ to inactivate the hydrolase and then it was centrifuged at $12,000 \times \mathrm{g}$ for $20 \mathrm{~min}$ to collect supernatants. The Degree of Hydrolysis (DH), protein content, IBC and Diphenyl-picryl hydrazyl radical Scavenging Ability (DSA) were determined.

\section{Experimental Design}

In the primary stage experiments confirm, the reaction time, temperature and enzyme addition quantity (E/S) were influenced significantly on the iron-binding capacity of hydrolysate. Therefore, these three independent hydrolysis conditions were investigated to obtain the maxium iron-binding ability by a Central Composite Design (CCD) in RSM. The $2^{\text {nd }}$-order designs were used in response surface methodology as acceptable approximation of true responses. The CCD design was very popular $2^{\text {nd }}$-order designs because of its extremely simple to use and allowing estimation of all the parameters in a full second-order model. Also, the CCD design was widely used for optimization of enzymatic hydrolysis of protein (Guo et al., 2009; Castro and Sato, 2015). Total 20 groups of parallel test were designed (with six reduplicative at the centre of the design). The axial distance $\alpha$ was chosen to be 1.68 in order to make this design orthogonal. The independent variables were shown in Table 2 and they were set according to preliminary experiment's conclusion. The codified values were labeled in Table 3 . From this design, these 20 experiments were executed. For the 3 levels CCD system, the $2^{\text {nd }}$-order polynomial equation was applied to fit IBC $\left(Y_{1}\right)$ and $\mathrm{DH}\left(Y_{2}\right)$ :

$\mathrm{Y} k=a_{0}+\sum_{i=1}^{4} a_{i} X_{i}+\sum_{i=1}^{4} a_{i i} X_{i i}+\sum_{i \neq j=1}^{4} a_{i j} X_{i j}$

where, $Y_{k}$ is predicted value, $a_{0}$ is the intercept, $a_{i}, a_{i i}$ and $a_{i j}$ are coefficients of the model. $X_{i}$ or $X_{j}$ are the coded factors. The data were analyzed by the Design Export (Statsoft, USA). The 3-D charts were constructed to reveal the interactive effects of the three factors. 
Table 1. Enzymatic hydrolysis conditions for tested proteases Parameters for enzymatic hydrolysis

\begin{tabular}{lllll} 
& & E $/ \mathrm{S}(\mathrm{U} / \mathrm{g})$ & $\mathrm{pH}$ & Temperature $\left({ }^{\circ} \mathrm{C}\right)$ \\
\hline Flavourzyme & 7500 & 4 & 7 & 50 \\
Trypsin & 7500 & 4 & 8 & 37 \\
Protamex & 7500 & 4 & 8 & 37 \\
Alcalse & 7500 & 4 & 8 & 50 \\
Flavourzyme & 7500 & 4 & 7 & 50 \\
\hline
\end{tabular}

Table 2. Coded levels of the hydrolysis parameters according to a central composite design for scad processing byproduct

\begin{tabular}{|c|c|c|c|c|c|c|}
\hline \multirow[b]{2}{*}{ Hydrolysis parameters } & \multicolumn{6}{|c|}{ Coded level } \\
\hline & Symbol & $-1.68(-\alpha)$ & -1 & 0 & 1 & $1.68(+\alpha)$ \\
\hline Temperature $\left({ }^{\circ} \mathrm{C}\right)$ & $X_{1}$ & 36.6 & 40 & 45 & 50 & 53.4 \\
\hline Time (min) & $X_{2}$ & 9.6 & 30 & 60 & 90 & 110.4 \\
\hline $\mathrm{E} / \mathrm{S}(\mathrm{U} / \mathrm{g})$ & $X_{3}$ & 4150 & 5000 & 6250 & 7500 & 8350 \\
\hline
\end{tabular}

Table 3. The iron-binding capacity and DH results of the CCD experiments

\begin{tabular}{|c|c|c|c|c|c|}
\hline \multirow[b]{2}{*}{ Experiment no. } & \multicolumn{5}{|l|}{ Factors } \\
\hline & $\begin{array}{l}\text { Temperature } \\
\left({ }^{\circ} \mathrm{C}, \text { Temp. }\right)\end{array}$ & Time (min) & E/S (U/g, ES) & $\begin{array}{l}\text { Iron-binding } \\
\text { capacity (ug/g) }\end{array}$ & DH (\%) \\
\hline 1 & 0 & 0 & -1.68 & $265.7 \pm 1.6$ & $61.8 \pm 4.9$ \\
\hline 2 & 0 & 0 & 0 & $328.9 \pm 9.2$ & $52.9 \pm 2.8$ \\
\hline 3 & -1.68 & 0 & 0 & $223.3 \pm 13.1$ & $58.5 \pm 3.4$ \\
\hline 4 & 0 & 0 & 0 & $318.3 \pm 4.1$ & $60.0 \pm 4.2$ \\
\hline 5 & 1 & -1 & 1 & $256.9 \pm 17.8$ & $61.8 \pm 2.4$ \\
\hline 6 & 0 & -1.68 & 0 & $279.6 \pm 5.6$ & $58.8 \pm 3.4$ \\
\hline 7 & 0 & 1.68 & 0 & $261.8 \pm 3.7$ & $64.4 \pm 2.8$ \\
\hline 8 & 1.68 & 0 & 0 & $261.9 \pm 6.8$ & $63.2 \pm 5.2$ \\
\hline 9 & 0 & 0 & 0 & $339.1 \pm 19.5$ & $51.5 \pm 4.1$ \\
\hline 10 & 1 & 1 & -1 & $287.1 \pm 3.8$ & $50.1 \pm 3.2$ \\
\hline 11 & -1 & -1 & -1 & $233.7 \pm 2.5$ & $48.7 \pm 4.4$ \\
\hline 12 & -1 & -1 & 1 & $259.9 \pm 9.0$ & $51.9 \pm 4.6$ \\
\hline 13 & 1 & 1 & 1 & $284.8 \pm 2.5$ & $58.1 \pm 1.1$ \\
\hline 14 & 0 & 0 & 0 & $306.2 \pm 3.7$ & $57.3 \pm 3.3$ \\
\hline 15 & 0 & 0 & 0 & $294.7 \pm 3.0$ & $56.4 \pm 4.5$ \\
\hline 16 & 0 & 0 & 1.68 & $275.9 \pm 1.4$ & $53.5 \pm 5.6$ \\
\hline 17 & -1 & 1 & 1 & $276.1 \pm 7.3$ & $59.8 \pm 4.0$ \\
\hline 18 & 1 & -1 & -1 & $273.7 \pm 15.4$ & $56.1 \pm 4.1$ \\
\hline 19 & -1 & 1 & -1 & $251.5 \pm 16.3$ & $57.1 \pm 8.1$ \\
\hline 20 & 0 & 0 & 0 & $308.3 \pm 5.0$ & $56.1 \pm 4.2$ \\
\hline
\end{tabular}

\section{Determination of the $\mathrm{DH}$}

The DH was tested by Peričin et al. (2009) method with a little modification. Simply, $0.5 \mathrm{~mL}$ hydrolysate and $0.5 \mathrm{~mL} 20 \%$ trichloroacetic acid was mixed to make the protein to precipitate at $4{ }^{\circ} \mathrm{C}$ for $3 \mathrm{~h}$. Thereafter, the mixture solution was centrifuged at $10000 \times \mathrm{g}$ for $20 \mathrm{~min}$ and the trichloroacetic acid soluble protein was determined by Folin-phenol method (Lowry et al., 1951). The DH value was expressed as the Equation 2:

$$
D H(\%)=\frac{\text { trichloroacetioacid soluble protein }}{\text { total protein }} \times 100 \%
$$

\section{Determination of IBC}

The IBC was determined using Chaud et al. (2002) method. When $\mathrm{Fe}^{3+}$ ions and thiocyanate ions in the solution were mixed, an intense red color developed. However, peptides in the solution compete with thiocyanate ions to bind free $\mathrm{Fe}^{3+}$ and the red color will fade. The sample was diluted by distilled water to $1.0 \mathrm{mg} \mathrm{mL}-1$ based on protein content. The $0.1 \mathrm{~mL}$ of $0.5 \%(\mathrm{w} / \mathrm{w}) \mathrm{FeCl}_{3}$ was added to the mixture of $4.2 \mathrm{~mL}$ sample solution and $0.1 \mathrm{~mL}$ of $1.0 \mathrm{M} \mathrm{KSCN}$. The reaction solution was incubated at $20^{\circ} \mathrm{C}$ for $20 \mathrm{~min}$. The OD value was then read at $484 \mathrm{~nm}$ and the iron concentration was obtained. The sample was replaced by distilled water to use as the control. The IBC was 
expressed as the bond iron qualities $(\mu \mathrm{g})$ per gram peptides in the solution.

\section{Determination of DSA}

The DSA was defined as Diphenyl Picryl Hydrazinyl (DPPH) radical scavenging activity and the determination was according to Sánchez-Moreno (2002) method with a little modification. The sample was diluted into $1.0 \mathrm{mg} \mathrm{mL}^{-1}$ based on protein content. A $1.0 \mathrm{~mL}$ sample was added to a test tube containing $3.0 \mathrm{~mL}$ ethanol and then $1.0 \mathrm{~mL}$ DPPH ethanol solution $(250 \mu \mathrm{M})$ was added. The mixture was incubated at $20^{\circ} \mathrm{C}$ for $30 \mathrm{~min}$ in dark in order to react completely and then the OD value was obtained at $517 \mathrm{~nm}$. The DSA was expressed as Equation 3:

$$
D S A(\%)=\left(1-\frac{A-A_{1}}{A_{0}}\right) \times 100 \%
$$

where, $A_{0}$ was the OD value of the blank, $A_{1}$ was back ground $\mathrm{OD}$ value and A was the OD value of the sample.

\section{Statistical Analysis}

Three parallel experiments were designed and the data were analyzed using ANOVA. The results were expressed as the means of triplicates \pm Standard Deviations (SD). The RSM results were statistically analyzed by Design-Expert (V8.0.5) software. The means differences were run by Least Significant Difference (LSD) at 5\% confidence level.

\section{Results and Discussion}

\section{Choice of Hydrolase}

Four kinds of hydrolysis enzymes, flavourzyme, protamex, trypsin and alcalase, were selected to prepare small peptides from SPB with iron-binding ability. The hydrolysis conditions were listed in Table 1. After hydrolysis for $4 \mathrm{~h}$, the hydrolysate was used to determine $\mathrm{DH}$ and IBC and the result was shown in Fig. 1. The DH had no significant difference $(P>0.05)$ between selected four commercial hydrolases and the $\mathrm{DH}$ was ranged at 39 to $42 \%$. However, the kinds of enzyme had significant effects on IBC. The IBC of hydrolysate with alcalase hydrolysis was significantly higher than the other three enzymes at $P<0.05$. As an endopeptidase, alcalase had a broad specificity of peptide bonds for protein hydrolysis, preferentially aromatic amino acids residues formatting peptide bonds, especially large uncharged residues (Peksa and Miedzianka, 2014). Therefore, alcalase was widely used for producing bioactive peptides from various proteins, such as ACE inhibitory peptides ( $\mathrm{Wu}$ et al., 2016), antioxidative peptides (Xia et al., 2012; Najafian and Babji, 2014), mineral-binding peptides (Kim et al., 2007), antimicrobial peptides (Liu et al., 2008) and anticoagulant peptides (Ren et al., 2014). So, alcalase was selected for next step to optimize hydrolysis conditions for producing small peptides from SPB with high iron binding ability.

\section{Effects of Hydrolysis Conditions}

During enzymatic hydrolysis process, more and more small peptides were liberated from protein and also the molecular weight of peptides was decreased. The bioactivity of hydrolysate, including iron-binding activity, changed during enzymatic hydrolysis. The changes in iron-binding ability and $\mathrm{DH}$ during alcalase hydrolysis of SPB were shown in Fig. 2a. During hydrolysis, the DH increased slowly, but its iron-binding ability did not always increased and it reached a peak at $60 \mathrm{~min}$. Then, the iron-binding ability significantly decreased, possibly due to peptides with high ironbinding ability hydrolyzed by alcalase into smaller peptides with lower iron-binding ability. This phenomenon also appeared in producing other biological peptides during enzymatic hydrolysis. The hydroxyl radical scavenging activity of Flavourzyme hydrolysate from barley glutelin protein first increased then decreased during $4 \mathrm{~h}$ hydrolysis process (Xia et al., 2012). Castro and Sato (2015) also reported that there had similar changes in antioxidative ability of egg white protein hydrolysates. Therefore, $60 \mathrm{~min}$ was selected as the hydrolysis time for further experiments.

The effects of hydrolysis temperature from 40 to $60^{\circ} \mathrm{C}$ on $\mathrm{DH}$ of SPB and iron-binding capacity of hydrolysate were determined at $\mathrm{pH}$ 8.0, shown in Fig. 2 b. The optimum temperature for hydrolysis of SPB by alcalase was at $45^{\circ} \mathrm{C}$. Also, the hydrolysate showed maximum IBC at $45^{\circ} \mathrm{C}$. Hence $45^{\circ} \mathrm{C}$ was chosen as center point in the next RSM experiments.

In order to study the effects of enzyme addition quantity on the iron-binding capacity, the hydrolysis process was carried out using different enzyme concentrations: 5000, 6250, 7500, 8750 and $10000 \mathrm{U} / \mathrm{g}$, results shown in Fig. 2c. The increase in E/S ratio caused an increasement of $\mathrm{DH}$ but not resulted in improved iron-binding ability and the iron binding ability swung between 100 and $200 \mu \mathrm{g} \mathrm{g}^{-1}$. Therefore, $6250 \mathrm{U} / \mathrm{g}$ was sufficient to obtain maximum iron-binding ability.

To study the effects of initial $\mathrm{pH}$ on the iron-binding ability of hydrolysate, the initial $\mathrm{pH}$ of hydrolysate was stabled at $\mathrm{pH} 7.0,7.5,8.0,8.5$ and 9.0. The result was shown in Fig. 2d. During alkaline $\mathrm{pH}$, the hydrolysate had higher $\mathrm{DH}$ because the alcalase had optimal $\mathrm{pH}$ at alkaline range. However, the IBC did not show the same tendency. The hydrolysate showed maximum iron-binding ability at pH 7.0 though it did not show the highest DH at this $\mathrm{pH}$. In order to obtain the high iron-binding ability, the initial $\mathrm{pH}$ of substrate was fixed at $\mathrm{pH}$ 7.0. 


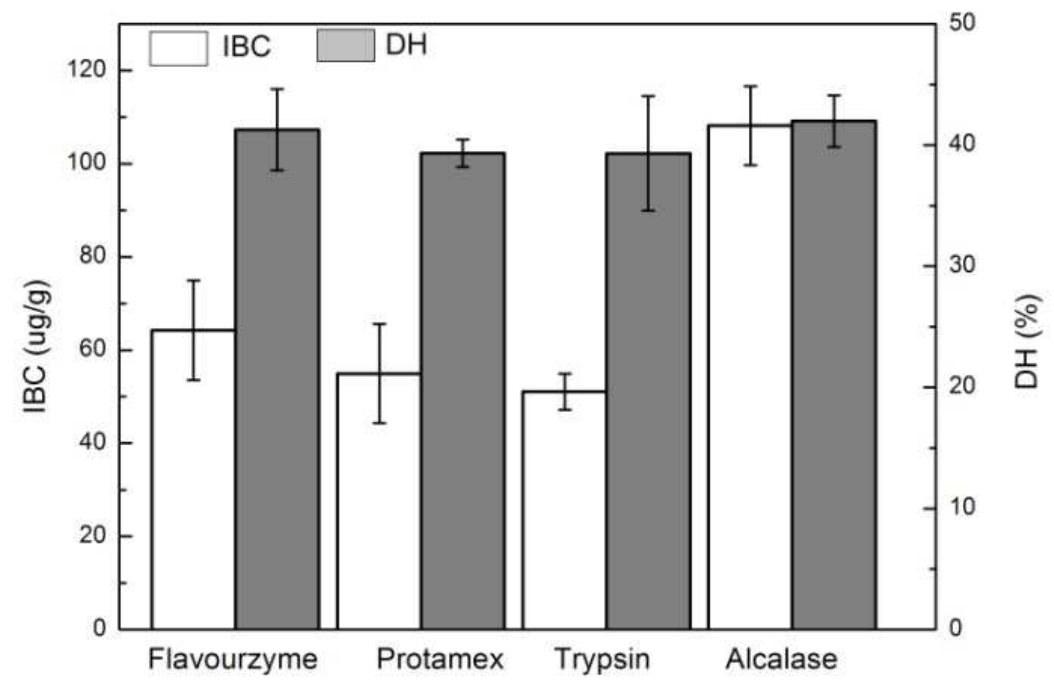

Fig. 1. The Iron-Binding Capacity (IBC) and Degree of Hydrolysis (DH) of scad processing byproduct with commercial proteases hydrolysis. The data was obtained by triplicate experiments
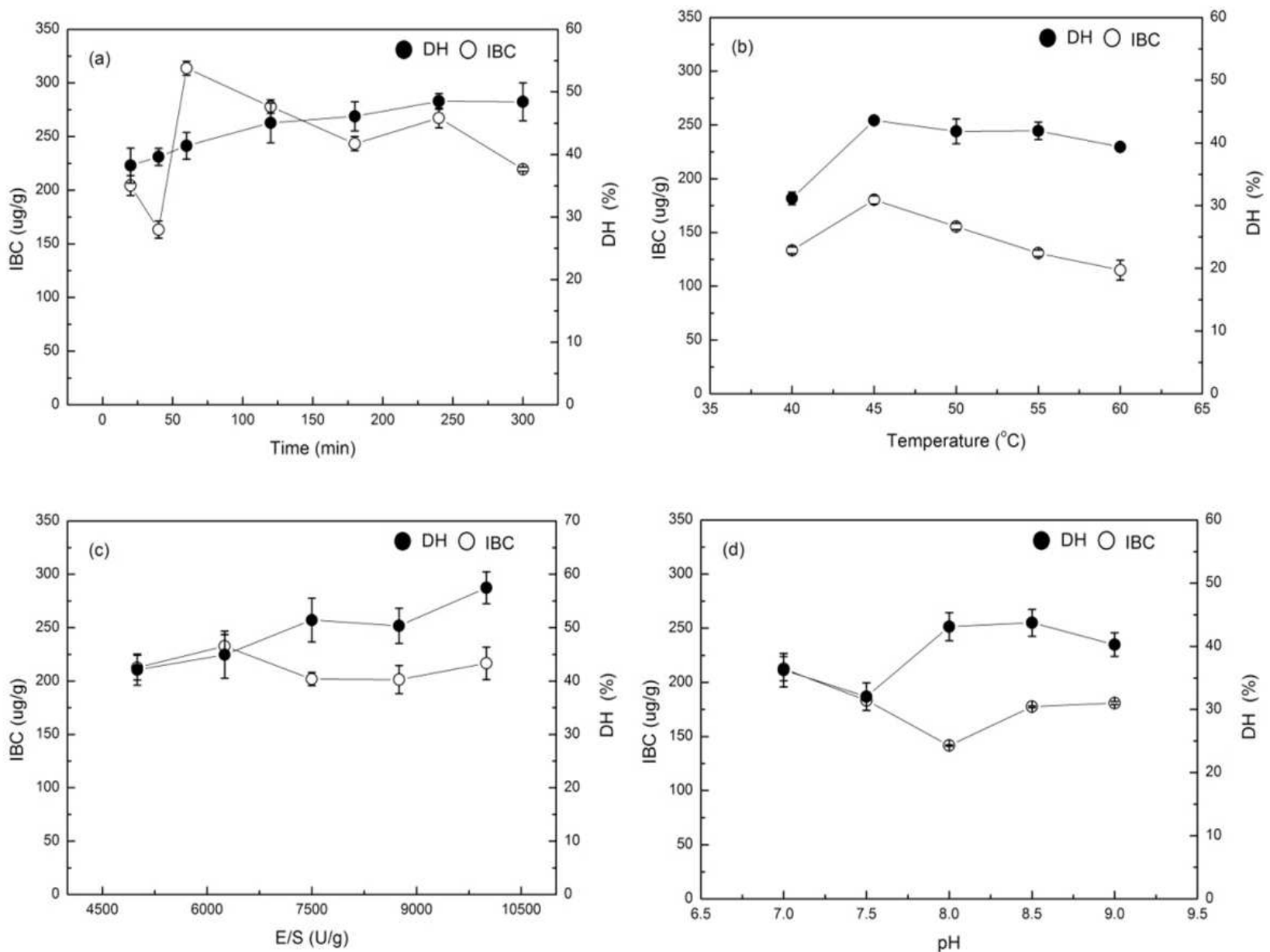

Fig. 2. Effects of hydrolysis time (a), hydrolysis temperature (b), enzyme substrate ration (E/S) (c), and hydrolysis pH (d) on IBC and DH. The data was obtained by triplicate experiments 


\section{Optimization by RSM}

The RSM experiments were carried out to optimize the alcalase hydrolysis conditions to get the maximum IBC hydrolysate. By the results of preliminary experiments, the temperature of $45^{\circ} \mathrm{C}$, time of $60 \mathrm{~min}$ and $\mathrm{E} / \mathrm{S}$ ratio of $6250 \mathrm{U} / \mathrm{g}$ were selected to be the center points of alcalase hydrolysis conditions. The CCD was applied to investigate the interactional effects of hydrolysis temperature, time and enzyme addition quantity on the IBC of SPB hydrolysate during alcalase hydrolysis. Independent coded variables were shown in Table 2. Total 20 runs were performed and the DH and IBC of hydrolysates were analyzed. The data were given in Table 3.

The multiple regression analysis was used to analyze the experimental data to obtain the parameters of the predicted model. A quadratic model as following explained the experimental data:

$$
\begin{aligned}
& I B C(\%)=315.73+18.02 X_{1}+3.32 X_{2} \\
& +3.59 X_{3}+1.52 X_{1} X_{2}-14.66 X_{1} X_{3} \\
& +1.60 X_{2} X_{3}-68.90 X_{1}^{2}-14.43 X_{2}^{2}-14.40 X_{3}^{2}
\end{aligned}
$$

The regression equation for IBC is highly significant shown in Table $4(\mathrm{~F}=7.36, \mathrm{p}<0.05)$. In trials, the first degree term $X^{2}$ (time) and quadratic term $X_{1}^{2} \quad$ (temperature), $X_{2}^{2}, \quad X_{3}^{2} \quad(\mathrm{E} / \mathrm{S})$ influenced significantly on IBC. However, interactive items did not affect significantly on the IBC. This result showed that during the process of the preparation of iron binding peptide, the influence of various factors on the IBC was not a simple linear relationship. The hydrolysis time, temperature and alcalase addition quantity were significantly affect on IBC. The interaction between various factors on the IBC did not have a significant impact.

The coefficient of $\mathrm{R}^{2}$ equals to 0.8688 indicated that the model has good precision. The $R^{2}$ (adj) of IBC was 0.7508 , indicating that $75.08 \%$ of the response on IBC could be explained by the model. Only $24.92 \%$ of total variation could not be explained by this mode. With the model of alcalase hydrolysis process of preparing iron binding peptide optimization was appropriate. The ANOVA shown in Table 4 also improved the model's lack of fit was not significant $(P>0.05)$, which conversely validated that the model was stable and could be used to predict the influence of various factors on the IBC. The 3-D charts were constructed to reveal the interactive effects of the three factors (Fig. 3). Though, the cross-interaction effects of time, temperature and alclase addition quantity $(\mathrm{E} / \mathrm{S})$ were not significant (Table 4), yet the suitable ranges of time, temperature and E/S would be known from Fig. 3 in order to obtain high IBC.
The optimal alcalase hydrolysis conditions were obtained by the predicted model as following: Hydrolysis temperature of $45.6^{\circ} \mathrm{C}, \mathrm{E} / \mathrm{S}$ of $6338 \mathrm{U} / \mathrm{g}$, hydrolysis time of $66.3 \mathrm{~min}$. The highest IBC by the predicted model was $317.2 \mu \mathrm{g} \mathrm{g}^{-1}$. According to these optimal hydrolysis conditions, we choose hydrolysis temperature of $46^{\circ} \mathrm{C}, \mathrm{E} / \mathrm{S}$ of $6340 \mathrm{U} / \mathrm{g}$, hydrolysis time of $66 \mathrm{~min}$ as a condition of hydrolysis, which was consistent with the average of three replicates of 296.2 $\mu \mathrm{g} \mathrm{g}^{-1}$ obtained in the validation experiments. The IBC of validated experiments was uniformity to that of predicted value. Therefore, the predict model for IBC during SPB enzymatic hydrolysis might be used for preparing hydrolysate with high IBC.

\section{Relationship of DH, DSA and IBC}

During enzymatic hydrolysis process, more and more small peptides are liberated from protein, that is to say, the DH of protein increased. Also the molecular weight of peptides was decreased. The bioactivity of hydrolysate, including iron-binding activity, varied during enzymatic hydrolysis. The relationships of DH and IBC, DH and DSA, IBC and DSA during hydrolysis process were shown in Fig. 4. The IBC of hydrolysate displays with the $\mathrm{DH}$ of protein during alcalase hydrolysis change was not consistent. The linearly dependent coefficient $r$ was only -0.3724 (Fig. 4a) and, the IBC did not display consistent with the DSA of hydrolysate and the linearly dependent coefficient $r$ was only -0.4499 (Fig. 4b). Also, the DSA did not show good relationship with $\mathrm{DH}$ and the linearly dependent coefficient $r$ was only 0.03371 (Fig. 4c). The DSA of hydrolysate had a little relationship to peptides molecular, but more depends on the amino acids compositions and sequence. Many studies had improved that high DSA of hydrolysate did not appeared at high DH point (Xia et al., 2012; Castro and Sato, 2015). Generally, the transition metal ions, including $\mathrm{Fe}^{2+}$ and $\mathrm{Cu}^{2+}$, promoted the oxidation of free radical. Therefore, the transition metal ions in solution chelated by other substance, such as EDTA and peptides, would decrease the oxidation of free radical. So, we investigated the hydrolysate with high IBC whether or not had high DSA. Because many enzymatic hyrolysate with high antioxidative ability had good transition metal ions chelating activity (Thiansilakul et al., 2007; Klompong et al., 2007; Agrawal et al., 2016). However, the antioxidative ability (DPPH radical scavenging activity) did not display linear relationship with IBC (Fig.4b) in this study, which might be because of the too narrow range of iron-binding ability (only from 251 to $349 \mu \mathrm{g} \mathrm{g}^{-1}$ ) and there were no data of IBC or DSA at lower value. In the next study, this should be considered. 

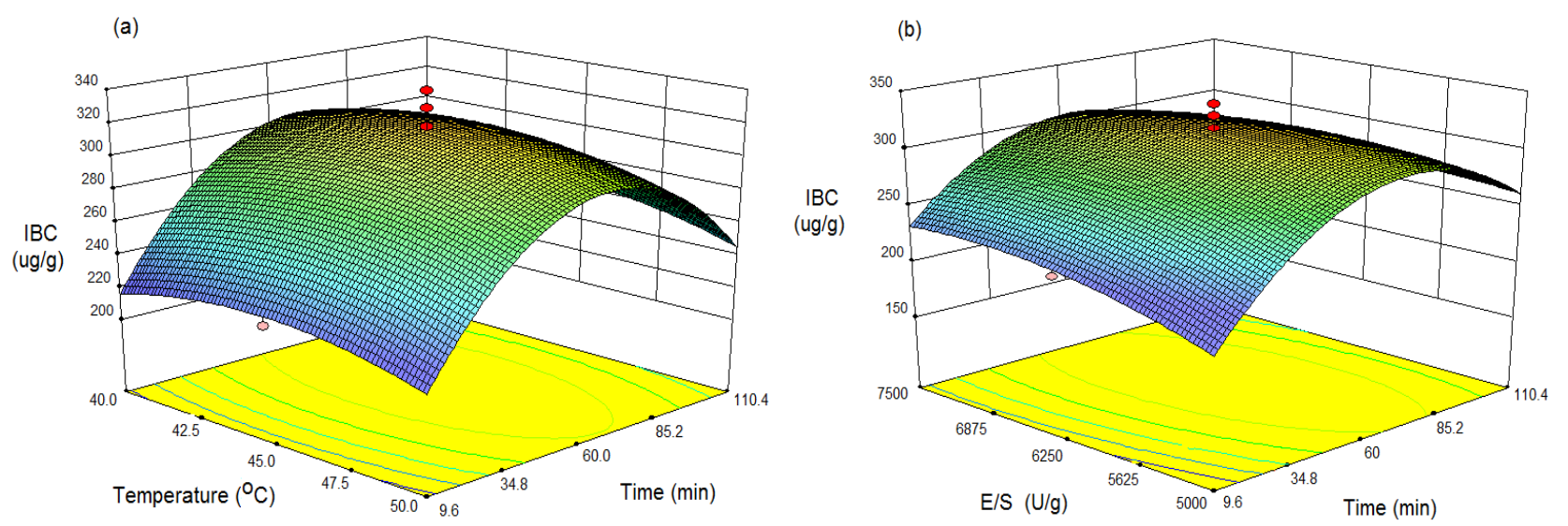

Fig. 3. The 3-D plots for the effects of variables on iron-binding capacity (IBC): (a) temperature and time; (b) time and E/S ratio
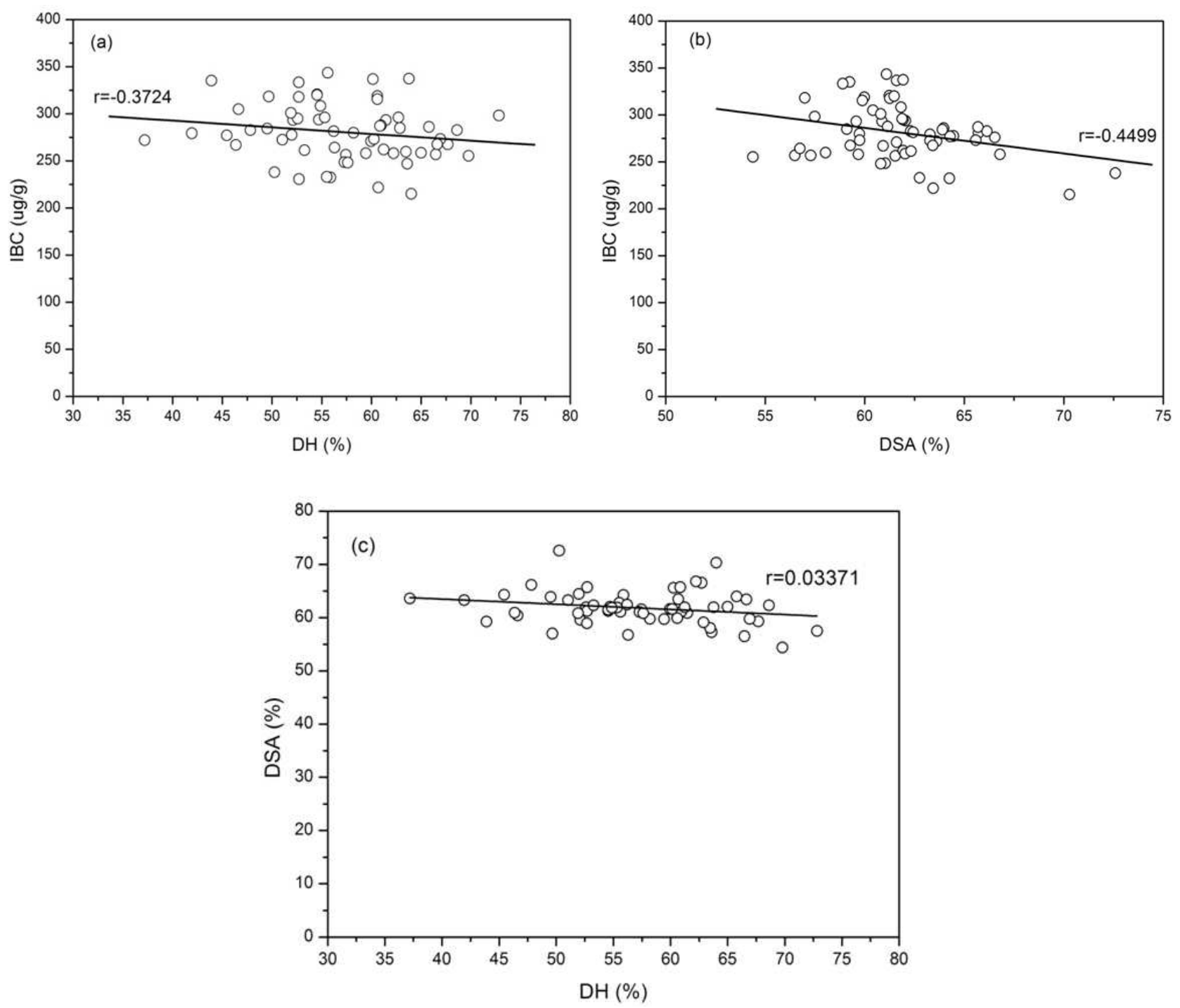

Fig. 4. The relationships of Iron-Binding Capacity (IBC), Degree of Hydrolysis (DH) and DPPH radical scavenging activity (DSA) 


\begin{tabular}{lllll}
\multicolumn{2}{l}{ Table 4. ANOVA for IBC } & & & \\
\hline Item & Sum of squares & df & $F$ Value & $p$-value \\
\hline Model & 14921.15 & 9 & 7.36 & $0.0022^{*}$ \\
$X_{1}$ : Temperature & 150.28 & 1 & 0.67 & 0.4331 \\
$X_{2}$ : Time & 1568.45 & 1 & 6.96 & $0.0248^{*}$ \\
$X_{3}$ E/S & 175.91 & 1 & 0.78 & 0.3976 \\
$X_{2} X_{1}$ & 6.58 & 1 & 0.029 & 0.8677 \\
$X_{2} X_{3}$ & 608.24 & 1 & 2.7 & 0.1314 \\
$X_{1} X_{3}$ & 20.6 & 1 & 0.091 & 0.7686 \\
$X_{2}{ }^{2}$ & 8550.98 & 1 & 37.96 & $0.0001^{*}$ \\
$X_{1}{ }^{2}$ & 3000.05 & 1 & 13.32 & $0.0045^{*}$ \\
$X_{3}$ & 2986.4 & 1 & 13.26 & $0.0045^{*}$ \\
Residual & 2252.91 & 10 & & 0.71 \\
Pack of fit & 935.51 & 5 & & 0.6418 \\
Cor total & $1.32 \mathrm{E}+03$ & 5 & & \\
\hline
\end{tabular}

\section{Conclusion}

The peptide-iron complexes, as a new type of iron supplement agents, increased the iron absorption in intestinal. The enzymatic hydrolysate with high ironbinding capacity from scad processing byproducts was investigated. The alcalase was the best protease within the four commercial enzymes for preparing high ironbinding capacity hydrolysate from SPB. The best hydrolysis conditions were optimized by RSM to be as following: Hydrolysis temperature of $46^{\circ} \mathrm{C}$, enzyme substrate ration of $6040 \mathrm{U} / \mathrm{g}$ and hydrolysis time of 66 min, respectively. The predicted iron-binding capacity was $317.2 \mu \mathrm{g} \mathrm{g}^{-1}$ at these optimal hydrolysis conditions, which was consistent with the average of three replicates of $296.2 \mu \mathrm{g} \mathrm{g} \mathrm{g}^{-1}$ obtained in the validation experiments. Future researches about ironbinding peptides purification, stability of iron-peptide complex and actual absorption in the intestinal cells are needed in order to improve the application as a new iron supplement agent.

\section{Acknowledgement}

This work was supported by the Science and Technology Project of Zhejiang Province, China (No. 2016C32064).

\section{Author's Contributions}

Wenting Zhang: Performed the experiments and wrote the manuscript.

Yanan Li and Jie Zhang: Participated in partial experiments.

Guangrong Huang: Developed the idea and analyzed the data.

\section{Ethics}

The authors declare that they had no conflict of interest.

\section{References}

Agrawal, H., R. Joshi and M. Gupta, 2016. Isolation, purification and characterization of antioxidative peptide of pearl millet (Pennisetum glaucum) protein hydrolysate. Food Chem., 204: 365-372. DOI: 10.1016/j.foodchem.2016.02.127

Battison, A.L., R. Summerfield and A. Patrzykat, 2008. Isolation and characterization of two antimicrobial peptides from haemocytes of the American lobster Homarus americanus. Fish Shellfish Immunol., 25: 181-187. DOI: 10.1016/j.fsi.2008.04.005

Castro, R.J.S. and H. Sato, 2015. A response surface approach on optimization of hydrolysis parameters for the production of egg white protein hydrolysates with antioxidant activities. Biocatalysis Agric. Biotechnol., 4: 55-62. DOI: $10.1016 /$ j.bcab.2014.07.001

Chaud, M.V., C. Izumi, Z. Nahaal, T. Shuhama and M.L.P. Bianchi et al., 2002. Iron derivatives from casein hydrolysates as a potential source in the treatment of iron deficiency. J. Agric. Food Chem., 50: 871-877. DOI: $10.1021 / \mathrm{jf0} 111312$

Cudennec, B., R. Ravallec-Ple, E. Courois and M. Fouchereau-Peron, 2008. Peptides from fish and crustacean by-products hydrolysates stimulate cholecystokinin release in STC-1 cells. Food Chem., 111: 970-975.

DOI: 10.1016/j.foodchem.2008.05.016

Forghani, B., M. Zarei, A. Ebrahimpour, R. Philip and J. Bakar et al., 2016. Purification and characterization of angiotensin converting enzymeinhibitory peptides derived from Stichopus horrens: Stability study against the ACE and inhibition kinetics. J. Functional Foods, 20: 276-290. DOI: 10.1016/j.biortech.2009.05.057

Fuqua, B.K., C.D. Vulpe and G.J. Anderson, 2012. Intestinal iron absorption. J. Trace Elements Med. Biol., 26: 115-119.

DOI: $10.1016 /$ j.jtemb.2012.03.015 
Guo, Y.X., D.D. Pan and M. Tanokura, 2009. Optimisation of hydrolysis conditions for the production of the Angiotensin-I Converting Enzyme (ACE) inhibitory peptides from whey protein using response surface methodology. Food Chem., 114: 328-333.

DOI: 10.1016/j.foodchem.2008.09.041

Huang, C.Y., C.H. Wu, J.I. Yang, Y.H. Li and J.M. Kuo, 2015. Evaluation of iron-binding activity of collagen peptides prepared from the scales of four cultivated fishes in Taiwan. J. Food Drug Analysis, 23: 671-678. DOI: 10.1016/j.jfda.2014.06.009

Huang, G.R., Z.Y. Ren, J.X. Jiang and W.W. Chen, 2012. Purification of a hepta-peptide with iron binding activity from shrimp processing byproducts hydrolysates. Adv. J. Food Sci. Technol., 4: 207-212.

Jiang, H., T. Tong, J. Sun, Y. Xu and Z. Zhao et al., 2014. Purification and characterization of antioxidative peptides from round scad (Decapterus maruadsi) muscle protein hydrolysate. Food Chem., 154: 158-163.

DOI: 10.1016/j.foodchem.2013.12.074

Jung, W.K. and S.K. Kim, 2007. Calcium-binding peptide derived from pepsinolytic hydrolysates of hoki (Johnius belengerii) frame. Eur. Food Res. Technol., 224: 763-767.

DOI: $10.1007 / \mathrm{s} 00217-006-0371-4$

Jung, W.K. and S.K. Kim, 2009. Isolation and characterization of an anticoagulant oligopeptide from blue mussel, Mytilus edulis. Food Chem., 117: 687-692. DOI: 10.1016/j.foodchem.2009.04.077

Kim, N.H., S.H. Jung, J. Kim, S.H. Kim and H.J. Ahn et al., 2014. Purification of an iron-chelating peptide from spirulina protein hydrolysates. J. Korean Society Applied Biol. Chem., 57: 91-95.

DOI: $10.1007 / \mathrm{s} 13765-013-4211-5$

Kim, S.B., I.S. Seo, M.A. Khan, K.S. Ki and W.S. Lee et al., 2007. Enzymatic hydrolysis of heated whey: Iron-binding ability of peptides and antigenic protein fractions. J. Dairy Sci., 90: 4033-4042.

DOI: $10.3168 /$ jds.2007-0228

Klompong, V., S. Benjakul, D. Kantachote and F. Shahidi, 2007. Antioxidative activity and functional properties of protein hydrolysate of yellow stripe trevally (Selaroides leptolepis) as influenced by the degree of hydrolysis and enzyme type. Food Chem., 102: 1317-1327.

DOI: 10.1016/j.foodchem.2006.07.016

Lee, T.G. and S. Maruyama, 1998. isolation of hiv-1 protease-inhibiting peptides from thermolysin hydrolysate of oyster proteins. Biochem. Biophys. Res. Commun., 253: 604-608.

DOI: $10.1006 /$ bbrc. 1998.9824
Liu, Z., S. Dong, J. Xu, M. Zeng and H. Song et al., 2008. Production of cysteine rich antimicrobial peptide by digestion of oyster (Crassostrea gigas) with alcalase and bromelin. Food Control., 19: 231-235.

DOI: 10.1016/j.foodcont.2007.03.004

Lowry, O.H., N.J. Rosebrough, A.L. Farr and R.J. Randall, 1951. Protein measurement with the Folin phenol reagent. J. Biol. Chem., 193: 265-275.

Najafian, L. and A.S. Babji, 2014. Production of bioactive peptides using enzymatic hydrolysis and identification antioxidative peptides from patin (Pangasius sutchi) sarcoplasmic protein hydolysate. J. Functional Foods 9: 280-289. DOI: $10.1016 /$ j.jff.2014.05.003

Peksa, A. and J. Miedzianka, 2014. Amino acid composition of enzymatically hydrolysed potato protein preparations. Czech J. Food Sci., 32: 265-272.

Peričin, D., L. Radulović-Popović, Ž. Vaštag, S. Mađarev-Popović and S. Trivić, 2009. Enzymatic hydrolysis of protein isolate from hull-less pumpkin oil cake: Application of response surface methodology. Food Chem., 115: 753-757. DOI: 10.1016/j.foodchem.2008.12.040

Picot, L., S. Bordenave, S. Didelot, I. Fruitier-Arnaudin and F. Sannier et al., 2006. Antiproliferative activity of fish protein hydrolysates on human breast cancer cell lines. Process Biochem., 41: 1217-1222. DOI: $10.1016 /$ j.procbio.2005.11.024

Ren, Y., H. Wu, F. Lai, M. Yang and X. Li et al., 2014. Isolation and identification of a novel anticoagulant peptide from enzymatic hydrolysates of scorpion (Buthus martensii Karsch) protein. Food Res. Int., 64: 931-938. DOI: $10.1016 /$ j.foodres.2014.08.031

Sánchez-Moreno, C., 2002. Methods used to evaluate the free radical scavenging activity in foods and biological systems. Food Sci. Technol. Int., 8: 121-137. DOI: 10.1106/108201302026770

Swain, J.H., L.B. Tabatabai and M.B. Reddy, 2002. Histidine content of low-molecular-weight beef proteins influences nonheme iron bioavailability in Caco-2 cells. J. Nutrition, 132: 245-251.

Thiansilakul, Y., S. Benjakul and F. Shahidi, 2007. Compositions, functional properties and antioxidative activity of protein hydrolysates prepared from round scad (Decapterus maruadsi). Food Chem., 103: 1385-1394.

DOI: 10.1016/j.foodchem.2006.10.055

Torres-Fuentes, C., M. Alaiz and J. Vioque, 2012. Ironchelating activity of chickpea protein hydrolysate peptides. Food Chem., 134: 1585-1588. DOI: 10.1016/j.foodchem.2012.03.112 
Wang, S., J. Zhao, L. Chen, Y. Zhou and J. Wu, 2014a. Preparation, isolation and hypothermia protection activity of antifreeze peptides from shark skin collagen. LWT-Food Sci. Technol., 55: 210-217. DOI: $10.1016 /$ j.lwt.2013.07.019

Wang, X., T. Ai, X.L. Meng, J. Zhou and X.Y. Mao, $2014 b$. In vitro iron absorption of $\alpha$-lactalbumin hydrolysate-iron and $\beta$-lactoglobulin hydrolysateiron complexes. J. Dairy Sci., 97: 2559-2566. DOI: $10.3168 /$ jds.2013-7461

Wu, H., Z. Liu, Y. Zhao and M. Zeng, 2012. Enzymatic preparation and characterization of iron-chelating peptides from anchovy (Engraulis japonicus) muscle protein. Food Res. Int., 48: 435-441.

DOI: 10.1016/j.foodres.2012.04.013

Wu, Q., J. Du, J. Jia and K. Cong, 2016. Production of ACE inhibitory peptides from sweet sorghum grain protein using alcalase: Hydrolysis kinetic, purification and molecular docking study. Food Chem., 199: 140-149.

DOI: 10.1016/j.foodchem.2015.12.012

Xia, Y., F. Bamdad, M. Ganzle and L. Chen, 2012. Fractionation and characterization of antioxidant peptides derived from barley glutelin by enzymatic hydrolysis. Food Chem., 134: 1509-1518.

DOI: $10.1016 /$ j.foodchem.2012.03.063
Zhang, M.N., G.R. Huang and J.X. Jiang, 2014. Iron binding capacity of dephytinised soy protein isolate hydrolysate as influenced by the degree of hydrolysis and enzyme type. J. Food Sci. Technol., 51: 994-999. DOI: 10.1007/s13197-011-0586-7

Zhang, W.T., J.Y. Sun and G.R. Huang, 2015. Stability of mackerel (Trachurus japonicas) hydrolysate with iron-binding capacity in simulated gastrointestinal fluids. Am. J. Food Technol., 10: 158-166. DOI: $10.3923 /$ ajft.2015.158.166

Zhong, C., Q.F. Cai, G.M. Liu, L.C. Sun and K. Hara et al., 2012. Purification and characterisation of cathepsin $\mathrm{L}$ from the skeletal muscle of blue scad (Decapterus maruadsi) and comparison of its role with myofibril-bound serine proteinase in the degradation of myofibrillar proteins. Food Chem., 133: 1560-1568. DOI: 10.3390/md13116550 